\title{
CORRECTIONS
}

\section{Doctors must not be lapdogs to drug firms}

Adriane Fugh-Berman, the author of this Personal View (BMJ 2006;333:1027, doi:10.1136/bmj.39024.654086.59), has advised us that she inadvertently neglected to disclose in her competing interests statement that at the time of the publication of this article she was and currently is "a paid expert witness on behalf of plaintiffs in litigation regarding pharmaceutical marketing practices." The original published statement can be found in the full version of her article (www.bmj.com/content/suppl/2006/ 11/09/333.7576.1027.DC1/pharma10no.pdf).

Cite this as: BMJ 2011;343:d6390

(๑) BMJ Publishing Group Ltd 2011 